\title{
Genetic polymorphisms of the $T L R 4$ gene and their association with susceptibility to type 2 diabetes mellitus in the Chinese population
}

\author{
X.D. Fu' ${ }^{1}$, X.Q. Sun ${ }^{2}$, H.Y. Wang ${ }^{1}$, J.F. Guo ${ }^{1}$, G.Z. Zhang ${ }^{1}$ and Q.H. Xu' ${ }^{1}$ \\ ${ }^{1}$ Department of Endocrinology, People's Hospital of Liaocheng, \\ Liaocheng, Shandong Province, China \\ ${ }^{2}$ Department of Endocrinology, Beijing Anzhen Hospital, \\ Capital University of Medical Sciences, Beijing, China \\ Corresponding author: J.F. Guo \\ E-mail: jianfei_guo@sina.com \\ Genet. Mol. Res. 12 (3): 3813-3820 (2013) \\ Received January 27, 2013 \\ Accepted August 26, 2013 \\ Published September 19, 2013 \\ DOI http://dx.doi.org/10.4238/2013.September.19.13
}

\begin{abstract}
Toll-like receptor 4 (TLR4) is potentially an important gene affecting the susceptibility to type 2 diabetes mellitus (T2DM). The objective of this study was to evaluate whether genetic polymorphisms of the TLR4 gene are associated with T2DM susceptibility. This potential association was analyzed in $668 \mathrm{~T} 2 \mathrm{DM}$ patients and 672 healthy controls by polymerase chain reaction-restriction fragment length polymorphism and DNA sequencing methods. Two novel genetic polymorphisms (g.12375A $>\mathrm{G}$ and g.14367G $>$ A) were investigated, and our data support the idea that the $\mathrm{g} .14367 \mathrm{G}>\mathrm{A}$ variant significantly increased susceptibility to T2DM in homozygote comparison (AA vs GG: $\mathrm{OR}=2.396,95 \% \mathrm{CI}=1.682-3.413, \mathrm{P}<0.0001$ ), heterozygote comparison $(\mathrm{GA}$ vs AA: $\mathrm{OR}=1.322,95 \% \mathrm{CI}=1.050-1.664, \mathrm{P}=$ $0.0175)$, dominant model $(\mathrm{AA} / \mathrm{GA}$ vs $\mathrm{GG}$ : $\mathrm{OR}=1.511,95 \% \mathrm{CI}=$ 1.217-1.876, $\mathrm{P}=0.0002$ ), recessive model (AA vs $\mathrm{GA} / \mathrm{GG}: \mathrm{OR}=2.093$, $95 \% \mathrm{CI}=1.496-2.927, \mathrm{P}<0.0001)$, and allele contrast $(\mathrm{A} v s \mathrm{G}: \mathrm{OR}=$ $1.503,95 \% \mathrm{CI}=1.279-1.766, \mathrm{P}<0.0001)$. The allele $\mathrm{A}$ of $\mathrm{g} .14367 \mathrm{G}>\mathrm{A}$
\end{abstract}


variants may contribute to the susceptibility to T2DM. However, we failed to detect a similar significantly increased susceptibility to T2DM in the g. $12375 \mathrm{~A}>\mathrm{G}$ variant. Our findings suggest that the g. $14367 \mathrm{G}>\mathrm{A}$ genetic polymorphism of the TLR4 gene is associated with the susceptibility to T2DM in the population studied.

Key words: Association analysis; Genetic polymorphisms; Susceptibility; Toll-like receptor 4; Type 2 diabetes mellitus

\section{INTRODUCTION}

Type 2 diabetes mellitus (T2DM), a complex chronic disease, is a significant global health problem. The incidence of T2DM is increasing rapidly in the world. It is estimated that six people die from the disease worldwide every minute (Wild et al., 2004; Arora et al., 2011). Recently, studies reported that there is a very high T2DM incidence in China where diabetes has become a major public health problem (Yang et al., 2010), with approximately 92.4 million adults with the disease and 148.2 million with prediabetes (Jiang et al., 2013). A large number of previous studies have shown that the human Toll-like receptor 4 (TLR4) is potentially an important gene influencing the susceptibility to T2DM (Illig et al., 2003; Rudofsky et al., 2004; Creely et al., 2007; Kim et al., 2008; Buraczynska et al., 2009; Arora et al., 2011; Maldonado-Bernal et al., 2011; Jiang et al., 2013). To date, several single nucleotide polymorphisms (SNPs) have been identified in the human TLR4 gene (Raby et al., 2002; Kolz et al., 2008; Arora et al., 2011; Jiang et al., 2013), such as Asp299Gly (Rudofsky et al., 2004; Kim et al., 2008; Buraczynska et al., 2009; Arora et al., 2011; Maldonado-Bernal et al., 2011; Jiang et al., 2013) and Thr399Ile (Rudofsky et al., 2004; Kim et al., 2008; Kolz et al., 2008; Buraczynska et al., 2009; Maldonado-Bernal et al., 2011; Jiang et al., 2013). Furthermore, several studies proved that the TLR4 gene variants were associated with susceptibility to T2DM (Rudofsky et al., 2004; Kim et al., 2008; Kolz et al., 2008; Buraczynska et al., 2009; Arora et al., 2011; Maldonado-Bernal et al., 2011; Jiang et al., 2013). However, the data from these studies are inconsistent, and the exact mechanism is poorly understood. To the best of our knowledge, there are no related studies on the association between the g.12375A $>\mathrm{G}$ and g. $14367 \mathrm{G}>\mathrm{A}$ genetic variants in the TLR4 gene and susceptibility to T2DM. Thus, the objective of the present study was to evaluate whether the g. $12375 \mathrm{~A}>\mathrm{G}$ and g.14367G $>$ A genetic variants of the TLR4 gene influence susceptibility to T2DM in the Chinese population.

\section{MATERIAL AND METHODS}

\section{Study population}

The study involved 668 patients with T2DM and 672 healthy controls who were consecutively enrolled between January 2010 and August 2012 in the People's Hospital of Liaocheng (People's Hospital of Liaocheng, Liaocheng, Shandong Province, China). All subjects were unrelated Han Chinese. All the healthy controls were matched with the patient population in terms of age, gender, and residence area, excluding those with a history of diabetes or other medical diseases. The T2DM patients were diagnosed by doctors according to the 2003 American Diabetes Association criteria (Genuth et al., 2003). Demographic and general characteristics on gender, age, body 
mass index, diabetes duration, systolic blood pressure, and diastolic blood pressure are summarized in Table 1 . The laboratory analytical methods for measuring triglycerides, total cholesterol, fasting plasma glucose (FPG), low-density lipoprotein cholesterol, and high-density lipoprotein cholesterol were described previously (Jing et al., 2011). The study protocol was approved by the Ethics Committee of the People's Hospital of Liaocheng, and all subjects gave written informed consent.

\section{Genotyping}

Genomic DNA was isolated from peripheral blood of patients and controls using a QIAamp DNA kit (Qiagen, Hilden, Germany). The polymerase chain reaction (PCR) primers were designed by the Primer Premier 5.0 software. The primer sequences, annealing temperature, and fragment sizes and region are presented in Table 2 . The TLR 4 genotype variants were detected by the PCR-restriction fragment length polymorphism (PCR-RFLP) technique and verified by DNA sequencing (ABI3730xl DNA Analyzer, Applied Biosystems, Foster City, CA, USA). PCRs were performed in a total volume of $20 \mu \mathrm{L}$, including 50 ng template DNA, $1 \mathrm{X}$ buffer (100 mM Tris-HCl, pH 8.3; $500 \mathrm{mM} \mathrm{KCl}), 0.25 \mu \mathrm{M}$ primers, $2.0 \mathrm{mM} \mathrm{MgCl}, 0.25 \mathrm{mM}$ dNTPs, and 0.5 U Taq DNA polymerase (Promega, Madison, WI, USA). PCR conditions were as follows: an initial denaturation at $94^{\circ} \mathrm{C}$ for $5 \mathrm{~min}$, followed by 33 cycles at $94^{\circ} \mathrm{C}$ for $32 \mathrm{~s}$, at the corresponding temperature (as presented in Table 2) for $32 \mathrm{~s}$, at $72^{\circ} \mathrm{C}$ for $32 \mathrm{~s}$, and a final extension at $72^{\circ} \mathrm{C}$ for $6 \mathrm{~min}$. The PCR amplified products were digested with $5 \mathrm{U}$ of restriction enzymes (MBI Fermentas, St. Leon-Rot, Germany; Table 2) at $37^{\circ} \mathrm{C}$ for $10 \mathrm{~h}$ following the manufacturer protocol. Digestion products were separated by electrophoresis on a $3 \%$ agarose gel containing $0.5 \mu \mathrm{g} / \mathrm{mL}$ ethidium bromide and visualized under UV light.

\section{Statistical analysis}

Statistical analyses were performed with the Statistical Package for Social Sciences software (SPSS, Windows version, release 15.0; SPSS Inc., Chicago, IL, USA). The chisquare $\left(\chi^{2}\right)$ test was used to evaluate Hardy-Weinberg equilibrium in allelic and genotypic frequencies, and to compare the differences of demographic and general characteristics between T2DM patients and healthy controls. Odds ratios (ORs) with their 95\% confidence intervals $(95 \% \mathrm{CIs})$ for the association analysis between allelic and genotypic frequencies and T2DM susceptibility were evaluated using multivariate logistic regression models. A P value $<0.05$ was defined as a statistically significant difference.

\section{RESULTS}

\section{General characteristics of subjects}

A total of 1340 subjects were collected in this case-control study, including 668 T2DM cases and 672 healthy controls. The demographic and general characteristics of subjects are shown in Table 1. There was no significant difference between T2DM patients and healthy controls with regard to gender and age $(\mathrm{P}=0.5146$ and $\mathrm{P}=0.3279$, respectively). We found that the clinical characteristics and anthropometric data were significantly different between the T2DM patients and healthy controls, as expected $(\mathrm{P}<0.001$; Table 1$)$. 
Table 1. Demographic and general characteristics of type 2 diabetes mellitus (T2DM) cases and healthy controls.

\begin{tabular}{lccc}
\hline Characteristics & T2DM cases $(\mathrm{N}=668)$ & Healthy controls $(\mathrm{N}=672)$ & P value \\
\hline Gender (male/female) & $342 / 326$ & $356 / 316$ & 0.5146 \\
Age (years) & $54.32 \pm 10.21$ & $55.28 \pm 9.87$ & 0.3279 \\
Body mass index $\left(\mathrm{kg} / \mathrm{m}^{2}\right)$ & $27.5 \pm 4.1$ & $24.31 \pm 3.6$ & $\mathrm{NA}$ \\
Diabetes duration $($ years) & $8.9 \pm 6.8$ & $113 \pm 12.8$ & $\mathrm{ND}$ \\
Systolic blood pressure $(\mathrm{mmHg})$ & $124.6 \pm 16.5$ & $75.2 \pm 6.7$ & $<0.001$ \\
Diastolic blood pressure $(\mathrm{mmHg})$ & $78.5 \pm 8.9$ & $5.18 \pm 0.48$ & $<0.001$ \\
Fasting plasma glucose $(\mathrm{mM})$ & $9.21 \pm 2.11$ & $4.29 \pm 1.11$ & $<0.001$ \\
Total cholesterol $(\mathrm{mM})$ & $4.98 \pm 1.21$ & $1.33 \pm 0.47$ & $<0.001$ \\
Triglycerides $(\mathrm{mM})$ & $1.92 \pm 1.62$ & $1.36 \pm 0.21$ & $<0.001$ \\
High-density lipoprotein cholesterol $(\mathrm{mM})$ & $1.12 \pm 0.18$ & $2.03 \pm 0.31$ & $<0.001$ \\
Low-density lipoprotein cholesterol $(\mathrm{mM})$ & $2.93 \pm 0.19$ & $<0.001$ \\
\hline
\end{tabular}

Data are reported as means \pm SD or numbers (\%). NA $=$ not applicable; ND $=$ not determined.

\section{Genotyping of TLR4 SNPs}

Two novel genetic variants (g.12375A $>$ G and g.14367G $>$ A) were detected by PCR-RFLP and DNA sequencing methods in this study. According to the sequence analysis, we found that the g. $12375 \mathrm{~A}>\mathrm{G}$ variant was an A to $\mathrm{G}$ mutation in intron 2 of the TLR4 gene. As for the g.14367G $>\mathrm{A}$ variant, sequence analysis detected that this was a $\mathrm{G}$ to $\mathrm{A}$ mutation in exon 3 of the TLR 4 gene, and that this caused a glutamic (Glu) to lysine (Lys) amino acid replacement (p.Glu474Lys, GenBank ID: NG_011475.1, NM_138554.4, and NP_612564.1). The PCR products of the g.12375A $>$ G polymorphism were digested with the TspEI restriction enzyme, electrophoresed, and divided into three genotypes: AA (177 and 50 bp), AG (227, 177, and 50 bp), and GG (227 bp; Table 2). Similarly, PCR products of the g.14367G $>$ A polymorphism were digested with the TaqI restriction enzyme and divided into three genotypes: GG (180 and $78 \mathrm{bp}), \mathrm{GA}(258,180$, and $78 \mathrm{bp})$, and AA (258 bp, Table 2). Table 3 shows the allele and genotype frequencies of the g.12375A $>\mathrm{G}$ and g.14367G $>\mathrm{A}$ variants in both T2DM patients and healthy subjects. Alleles $A$ and $G$ were predominant alleles of g. $12375 \mathrm{~A}>\mathrm{G}$ and g. $14367 \mathrm{G}>\mathrm{A}$ in the subjects studied, respectively. The genotype frequencies of the two variants in the populations studied did not significantly deviate from Hardy-Weinberg equilibrium (for T2DM patients, $\chi^{2}=0.1684$ and $\chi^{2}=4.8824$, respectively; for healthy controls, $\chi^{2}=0.5399$ and $\chi^{2}$ $=0.0540$, respectively; all $\mathrm{P}$ values $>0.05$ ). For the g. $14367 \mathrm{G}>\mathrm{A}$ variant, the allele frequencies of T2DM patients (G: 61.60\%; A: 38.40\%) were highly significantly different from healthy controls (G: $70.68 \%$; A: $\left.29.32 \%, \chi^{2}=24.6864, \mathrm{P}<0.0001\right)$. In addition, the genotype frequencies in T2DM patients were not consistent with the healthy controls, with the differences being statistically significant $\left(\chi^{2}=24.8269, \mathrm{P}<0.0001\right.$, Table 3$)$. For the g.12375A $>\mathrm{G}$ variant, the allele and genotype frequencies of T2DM patients were not consistent with healthy controls, but the differences were not statistically significant $\left(\chi^{2}=1.2491, \mathrm{P}=0.2637\right.$, and $\chi^{2}=1.2775, \mathrm{P}=0.5280$; Table 3$)$.

Table 2. Primer and PCR-RFLP analysis for genotyping the TLR4 gene polymorphism.

\begin{tabular}{|c|c|c|c|c|c|c|}
\hline$\overline{\text { SNPs }}$ & Primer sequences & $\begin{array}{c}\text { Annealing } \\
\text { temperature }\left({ }^{\circ} \mathrm{C}\right)\end{array}$ & $\begin{array}{l}\text { Amplification } \\
\text { fragment (bp) }\end{array}$ & Region & $\begin{array}{c}\text { Restriction } \\
\text { enzyme }\end{array}$ & Genotype (bp) \\
\hline g. $12375 \mathrm{~A}>\mathrm{G}$ & $\begin{array}{l}\text { 5'-CATTGGCTTGCTGTTTGCTGG-3' } \\
\text { 5'-GGAGGAATCATGACAAATAGCTTCC-3' }\end{array}$ & 64.0 & 227 & Intron 2 & $T s p \mathrm{EI}$ & $\begin{array}{l}\text { AA: } 177,50 \\
\text { AG: } 227,177,50 \\
\text { GG: } 227\end{array}$ \\
\hline g. $14367 \mathrm{G}>A$ & $\begin{array}{l}\text { 5'-CATGAGTTCAAACTTCTTGGG-3' } \\
\text { 5'-GTCAAGTTTCTCAGCTCTGTGAAG-3' }\end{array}$ & 59.0 & 258 & Exon 3 & TaqI & $\begin{array}{l}\text { GG: } 180,78 \\
\text { GA: } 258,180,78 \\
\text { AA: } 258\end{array}$ \\
\hline
\end{tabular}

$\overline{\mathrm{SNPs}}=$ single nucleotide polymorphisms; PCR-RFLP $=$ polymerase chain reaction-restriction fragment length polymorphism. 


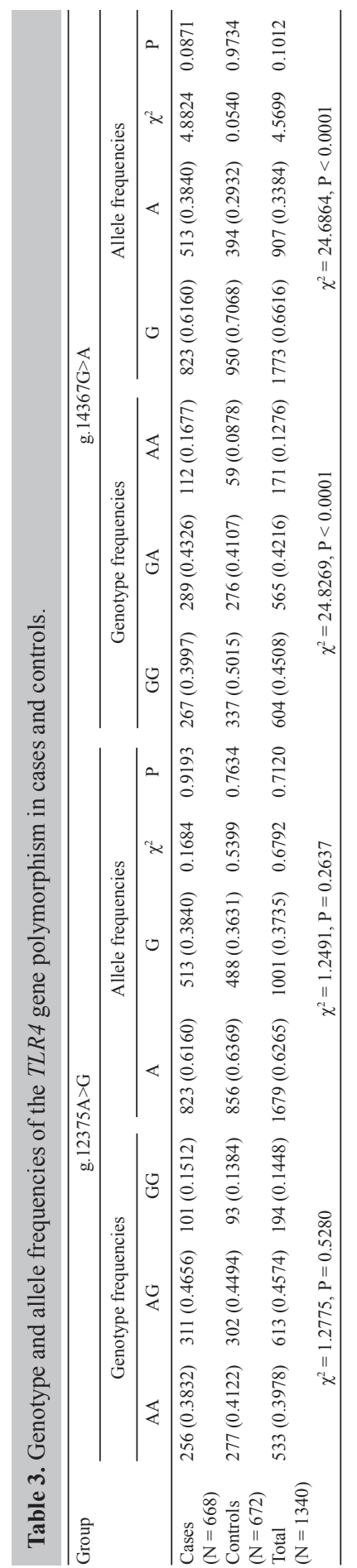




\section{$T L R 4$ variants and susceptibility to T2DM}

Table 4 shows that the alleles and genotypes from the g. $14367 \mathrm{G}>\mathrm{A}$ variants were statistically associated with susceptibility to T2DM. There was significantly increased susceptibility to $\mathrm{T} 2 \mathrm{DM}$ in the homozygote comparison (AA $v s \mathrm{GG}$ : $\mathrm{OR}=2.396,95 \% \mathrm{CI}=1.682-3.413, \chi^{2}=$ 24.18, $\mathrm{P}<0.0001$ ), heterozygote comparison (GA vs GG: $\mathrm{OR}=1.322,95 \% \mathrm{CI}=1.050-1.664$, $\left.\chi^{2}=5.65, \mathrm{P}=0.0175\right)$, dominant model $\left(\mathrm{AA} / \mathrm{GA} v s \mathrm{GG}: \mathrm{OR}=1.511,95 \% \mathrm{CI}=1.217-1.876, \chi^{2}\right.$ $=14.02, \mathrm{P}=0.0002)$, recessive model $\left(\mathrm{AA} v s \mathrm{GA} / \mathrm{GG}: \mathrm{OR}=2.093,95 \% \mathrm{CI}=1.496-2.927, \chi^{2}=\right.$ $19.19, \mathrm{P}<0.0001)$, and allele contrast (A vs $\mathrm{G}: \mathrm{OR}=1.503,95 \% \mathrm{CI}=1.279-1.766, \chi^{2}=24.69$, $\mathrm{P}<0.0001$; Table 4). However, as shown in Table 4, for the g. $12375 \mathrm{~A}>\mathrm{G}$ variant there was no significant difference in susceptibility to T2DM in any genetic model $(\mathrm{P}>0.05$; Table 4$)$.

\begin{tabular}{|c|c|c|c|c|}
\hline \multirow[t]{2}{*}{ SNPs } & \multirow[t]{2}{*}{ Comparisons } & \multicolumn{3}{|c|}{ Test of association } \\
\hline & & OR $(95 \% \mathrm{CI})$ & $\chi^{2}$ value & $P$ value \\
\hline \multirow[t]{5}{*}{ g. $12375 \mathrm{~A}>\mathrm{G}$} & $\begin{array}{l}\text { Homozygote comparison } \\
\text { (GG vs AA) }\end{array}$ & $1.175(0.846-1.663)$ & 0.93 & 0.3361 \\
\hline & $\begin{array}{l}\text { Heterozygote comparison } \\
\text { (AG vs AA) }\end{array}$ & $1.114(0.883-1.406)$ & 0.83 & 0.3611 \\
\hline & $\begin{array}{l}\text { Dominant model } \\
\text { (GG/AG vs AA) }\end{array}$ & $1.129(0.907-1.405)$ & 1.17 & 0.2787 \\
\hline & $\begin{array}{l}\text { Recessive model } \\
\text { (GG vs AG/AA) }\end{array}$ & $1.109(0.818-1.504)$ & 0.44 & 0.5054 \\
\hline & $\begin{array}{l}\text { Allele contrast } \\
(\mathrm{G} v s \mathrm{~A})\end{array}$ & $1.093(0.935-1.279)$ & 1.25 & 0.2637 \\
\hline \multirow[t]{5}{*}{ g. $14367 \mathrm{G}>A$} & $\begin{array}{l}\text { Homozygote comparison } \\
\text { (AA vs GG) }\end{array}$ & $2.396(1.682-3.413)$ & 24.18 & $<0.0001$ \\
\hline & $\begin{array}{l}\text { Heterozygote comparison } \\
\text { (GA vs } \mathrm{GG} \text { ) }\end{array}$ & $1.322(1.050-1.664)$ & 5.65 & 0.0175 \\
\hline & $\begin{array}{l}\text { Dominant model } \\
\left(\mathrm{AA} / \mathrm{GA} v_{S} \mathrm{GG}\right)\end{array}$ & $1.511(1.217-1.876)$ & 14.02 & 0.0002 \\
\hline & $\begin{array}{l}\text { Recessive model } \\
\text { (AA } v s \mathrm{GA} / \mathrm{GG} \text { ) }\end{array}$ & $2.093(1.496-2.927)$ & 19.19 & 0.0001 \\
\hline & $\begin{array}{l}\text { Allele contrast } \\
\left(\text { A } v_{S} \mathrm{G}\right)\end{array}$ & $1.503(1.279-1.766)$ & 24.69 & $<0.0001$ \\
\hline
\end{tabular}

\section{DISCUSSION}

T2DM is a complex polygenic disease resulting from complex interactions between multiple environmental and genetic factors (Permutt et al., 2005; Freeman and Cox, 2006; Liu et al., 2011; Al-Daghri et al., 2012; Gan and Yang, 2012; Gonul et al., 2012). Genetic factors play key roles in the pathogenesis of T2DM. TLR4 is one of the most important candidate genes for T2DM, and genetic variants in the TLR4 gene have been reported to be associated with T2DM susceptibility (Illig et al., 2003; Rudofsky et al., 2004; Creely et al., 2007; Kim et al., 2008; Buraczynska et al., 2009; Arora et al., 2011; Maldonado-Bernal et al., 2011; Jiang et al., 2013). In this study, we demonstrated an association between the g.12375A $>\mathrm{G}$ and g. $14367 \mathrm{G}>\mathrm{A}$ genetic variants of the TLR4 gene and the risk of T2DM in the Chinese Han population. Our data showed the distribution differences in the allele and genotype frequencies between T2DM patients and healthy controls (Table 3 ). In addition, the g.14367G $>$ A genetic variant was strongly associated with increased susceptibility to T2DM in the Chinese Han population. The allele A 
could contribute to the risk of occurrence of T2DM. In contrast, there was no significantly increased susceptibility to T2DM in the g.12375A $>$ G variants (Table 4). To date, several studies have been investigating the role of TLR4 gene polymorphisms on the risk of T2DM, but none included the g. 12375A $>$ G and g. 14367G $>$ A polymorphisms. Most studies have focused on two SNPs, Asp299Gly (Rudofsky et al., 2004; Kim et al., 2008; Buraczynska et al., 2009; Arora et al., 2011; Maldonado-Bernal et al., 2011; Jiang et al., 2013) and Thr399Ile (Rudofsky et al., 2004; Kim et al., 2008; Kolz et al., 2008; Buraczynska et al., 2009; Maldonado-Bernal et al., 2011; Jiang et al., 2013). However, the results from these studies are inconclusive. Our findings suggested that the g. $12375 \mathrm{~A}>\mathrm{G}$ and g. $14367 \mathrm{G}>\mathrm{A}$ genetic variants in the TLR4 gene are associated with increased susceptibility to T2DM in the Chinese population. Results from this study should assist in understanding the role of the TLR4 gene in T2DM.

In summary, this is the first study evaluating the association between the g. $12375 \mathrm{~A}>\mathrm{G}$ and g. $14367 \mathrm{G}>\mathrm{A}$ genetic variants of the TLR 4 gene and susceptibility to T2DM. Our findings suggest that the $\mathrm{g} .14367 \mathrm{G}>\mathrm{A}$ genetic polymorphism of the TLR4 gene is strongly associated with susceptibility to T2DM, and the TLR4 genetic variants may serve as molecular marker for assessing the risk of T2DM. However, further studies are required to determine if these results apply to larger populations of different ethnicities.

\section{Conflicts of interest}

The authors declare that they have no conflicts of interest.

\section{REFERENCES}

Al-Daghri NM, Al-Attas OS, Alokail MS, Alkharfy KM, et al. (2012). Adiponectin gene polymorphisms (T45G and G276T), adiponectin levels and risk for metabolic diseases in an Arab population. Gene 493: 142-147.

Arora P, Garcia-Bailo B, Dastani Z, Brenner D, et al. (2011). Genetic polymorphisms of innate immunity-related inflammatory pathways and their association with factors related to type 2 diabetes. BMC Med. Genet. 12: 95.

Buraczynska M, Baranowicz-Gaszczyk I, Tarach J and Ksiazek A (2009). Toll-like receptor 4 gene polymorphism and early onset of diabetic retinopathy in patients with type 2 diabetes. Hum. Immunol. 70: 121-124.

Creely SJ, McTernan PG, Kusminski CM, Fisher F, et al. (2007). Lipopolysaccharide activates an innate immune system response in human adipose tissue in obesity and type 2 diabetes. Am. J. Physiol. Endocrinol. Metab. 292: E740-E747.

Freeman H and Cox RD (2006). Type-2 diabetes: a cocktail of genetic discovery. Hum. Mol. Genet. 15 Spec No 2: R202-R209.

Gan RT and Yang SS (2012). The $223 \mathrm{~A}>\mathrm{G}$ polymorphism of the leptin receptor gene is associated with macroangiopathy in type 2 diabetes mellitus. Mol. Biol. Rep. 39: 4759-4764.

Genuth S, Alberti KG, Bennett P, Buse J, et al. (2003). Follow-up report on the diagnosis of diabetes mellitus. Diabetes Care 26: 3160-3167.

Gonul N, Kadioglu E, Kocabas NA, Ozkaya M, et al. (2012). The role of GSTM1, GSTT1, GSTP1, and OGG1 polymorphisms in type 2 diabetes mellitus risk: a case-control study in a Turkish population. Gene 505: 121-127.

Illig T, Bongardt F, Schopfer A, Holle R, et al. (2003). The endotoxin receptor TLR4 polymorphism is not associated with diabetes or components of the metabolic syndrome. Diabetes 52: 2861-2864.

Jiang ZS, Wang SX, Jia HX, Wang J, et al. (2013). Association of toll-like receptor 4 polymorphisms with type 2 diabetes mellitus. Inflammation 36: 251-257.

Jing Y, Zhu D, Bi Y, Yang D, et al. (2011). Monocyte chemoattractant protein 1-2518 A/G polymorphism and susceptibility to type 2 diabetes in a Chinese population. Clin. Chim. Acta 412: 466-469.

Kim YS, Hwang YJ, Kim SY, Yang SM, et al. (2008). Rarity of TLR4 Asp299Gly and Thr399lle polymorphisms in the Korean population. Yonsei Med. J. 49: 58-62.

Kolz M, Baumert J, Muller M, Khuseyinova N, et al. (2008). Association between variations in the TLR4 gene and incident type 2 diabetes is modified by the ratio of total cholesterol to HDL-cholesterol. BMC Med. Genet. 9: 9. 
Liu J, Chen X, Guo Q, Ma X, et al. (2011). Association of ARHGEF11 R1467H polymorphism with risk for type 2 diabetes mellitus and insulin resistance in Chinese population. Mol. Biol. Rep. 38: 2499-2505.

Maldonado-Bernal C, Trejo-de la O A, Sánchez-Contreras ME, Wacher-Rodarte N, et al. (2011). Low frequency of Tolllike receptors 2 and 4 gene polymorphisms in Mexican patients and their association with type 2 diabetes. Int. $J$. Immunogenet. 38: 519-523.

Permutt MA, Wasson J and Cox N (2005). Genetic epidemiology of diabetes. J. Clin. Invest. 115: 1431-1439.

Raby BA, Klimecki WT, Laprise C, Renaud Y, et al. (2002). Polymorphisms in toll-like receptor 4 are not associated with asthma or atopy-related phenotypes. Am. J. Respir. Crit. Care Med. 166: 1449-1456.

Rudofsky G Jr, Reismann P, Witte S, Humpert PM, et al. (2004). Asp299Gly and Thr399Ile genotypes of the TLR4 gene are associated with a reduced prevalence of diabetic neuropathy in patients with type 2 diabetes. Diabetes Care 27: 179-183.

Wild S, Roglic G, Green A, Sicree R, et al. (2004). Global prevalence of diabetes: estimates for the year 2000 and projections for 2030. Diabetes Care 27: 1047-1053.

Yang SH, Dou KF and Song WJ (2010). Prevalence of diabetes among men and women in China. N. Engl. J. Med. 362 : $2425-2426$. 